\title{
STRATEGIES USED BY GIFTED STUDENTS FOR MEMORIZING ENGLISH VOCABULARY AT ENGLISH DEPARTMENT OF IAIN PADANG SIDEMPUAN
}

\author{
Sojuangon Rambe \\ Institut Agama Islam Negeri (IAIN) Padang Sidempuan \\ email: sojuangonr@gmail.com
}

\begin{abstract}
This research was triggered by the lacking of studies exploring vocabulary learning strategies, especially concerning vocabulary memory strategies used by the gifted English learners, but actually the case is that many experts and researchers suggest and find that vocabulary memory strategy affecting learners' vocabulary mastery. Therefore, it is accredited that vocabulary mastery is the most affecting factor on language proficiency. Accordingly, this study was conducted by using quantitative-descriptive design by involving all gifted students at English Deparment of IAIN Padangsidimpuan as respondents. Data collection was conducted by administering questionnaire and conducting interview. Therefore, check and recheck technique was conducted to maintain data validity. Finally the data analysis was performed by using simple calculations presenting the logical features of the collected data. The findings showed the high variety of respondents answers to the questionnaire's items, however the 27 items of strategies listed in Schmitt and Mc Charty's (1997) is presented based on frequency of use as follows: Strategy $14>16>20>10=1>2>23=17=3>15>12>4>22=11>21=5>$ $24>25=13>26>9>6>7>27=18>8$. Besides, there are 8 other strategies used by the respondents to memorize English vocabulary not listed in the package.
\end{abstract}

Keyword: strategies, use, gifted students, vocabulary, vocabulary memory strategies 


\section{INTRODUCTION}

Despite the poor attention to the vocabulary instruction nowadays, vocabulary is generally perceived as the heart of language. Brown (1994) declares that vocabulary has central role in contextualized, meaningful language. Vocabulary plays a significant role for communication, because the communication will stop if people hear or read words that people fail to understand (Scott, Jamieson-Noel \&Asselin, 2003 in Zahedi and Abdi, 2012). Without mastering adequate vocabulary one will not be able to communicate in a certain language. On the other hand, if one master a lot of vocabulary items he or she will surely be able to accomplish language skills. Few arguments about the important vocabulary in communication presented below:

First, fluency in speaking is closely related to mastery of vocabulary. There are at least two sources of weaknesses which cause hesitance in speaking foreign language: vocabulary and grammar, from the two factors, vocabulary stands as the most determining one. When someone speaks a foreign language, he usually tends to be more frequently pausing his talk due to lack of vocabulary rather than lack of grammar mastery. It is due to that words cannot come by themselves when someone is communicating. They must have been in one's head before he/she communicates with others. On the other hand, one can construct utterances while communicating if he has the words, although the structure is very possibly wrong. In fact, speech is frequently understandable even though the structure is not correct.

Strengthening the statement, an interesting fact was revealed through the writer's interview to a number of successful English and Arabic learners who are the alumni of Islamic Boarding Schools (Pondok Pesantren) in Indonesia. Although their majors are not English or Arabic, their English and Arabic are excellent. They confessed that the exposure to English and Arabic communication regulated by the Islamic schools worked successfully when the students (themselves) possessed a lot of vocabulary. Therefore, the structure came in the process of their struggling to communicate.

Second, similar to speaking, expressing ideas in writing cannot be done well unless one possesses enough vocabulary. It is due to that when someone is to write something, he or she will come to the question of what words to use, how they are look like (written) and then what structure to make them orderly to convey meaning correctly. Unless one has the words in his or her head, the writing will be impossible. Therefore, people who write texts by employing a very limited vocabulary, their writing will seem to be dull. Although the meaning is conveyed 
appropriately, the limited words will make the texts poor due to the repetition of similar words to express same meanings.

Third, reading comprehension is impossible without the mastery of vocabulary. Reading concerns with facing texts which consist of words. If the reader does not know the words, he or she will be automatically cannot get information from it. Although a number of reading strategies like skimming and summarizing offer ways to get meaning from texts by picking certain sentences from the paragraphs, they actually cannot be applied successfully without enough vocabulary in part of the readers. There is always large possibility for them to pick wrong sentences. And if suppose they pick correct ones, it doesn't mean that they comprehend the text. Similarly, inference clues strategies cannot be successful without adequate vocabulary. When the strategy demands the reader to analyze the surrounding of a difficult word, he will be blocked if he doesn't know the meaning of the surrounding words. Additionally, Noor and Amir (2009) had found that the higher vocabulary mastery of the students, the higher is their reading comprehension achievement.

The last, listening comprehension is impossible without mastery of vocabulary. Listening comprehension activity is about gathering meanings of words listened either lexically or contextually. A listener is demanded to identify what words are involved in text that he or she listens to. After getting the lexical meaning, he or she will be challenged to generate more correct meaning based on the contexts. After that, he will be able to give appropriate response. Unless the listener knows the words, he or she will very possibly give wrong response. This problem constantly happens in listening comprehension as test and as real life communication.

From the arguments above, it is clear that vocabulary mastery is the basic need of communication. It is impossible to communicate in any language without mastery of words. Accordingly, language curriculum must be equipped with programs to make students master a certain amount of words which will help them to communicate effectively. The writer further believes that underestimation of vocabulary mastery in part of students is the main cause of failure of teaching second and foreign languages in many countries in the planet.

English teaching in Indonesia and may also be in many other Non-English speaking countries are poor in term of vocabulary teaching. Based on the shown characteristics, English curriculum in Indonesia today combines some approaches: Genre Based Approach and Competency Based Approach in Junior and Senior High School, and ESP and/or Competency Based Approach in Vocational Schools. As a matter of fact, none of them gives enough emphasis on vocabulary development in part of students. As a result, although 
according to the governmental system, students graduating from high schools have passed high passing grade in English, the writer as an English lecturer of a college always finds contrary facts about their ability. This truth signs the failure of language teaching due to ignorance to vocabulary mastery. Occurrence of such situation in variety contexts must be the reason for Seal (1991) to predict that this period will be ended and then the future era of language teaching will place vocabulary in language learning process and as an area of research with restored respectability and prominence like the old time.

Above all, without giving any further blame and accusation to whomever in education systems, learning is widely agreed as part of students. We have to shift to the new paradigm: from teaching to learning, from teaching strategies to learning strategies and more progressively from instruction to construction. Brown (1994) points out that teacher's mission is to enable learners to eventually become independent of the classroom. He further names learning strategy as 'investment' in part of students. More progressively, Ghazal (2007) points out that one way to alley the burden is to assist students in becoming independent learners during the process of L2 vocabulary learning. We have to unravel the ironical fact about vocabulary learning in the schools where most of the learners do not have a clue about how to memorize new words, how to combine the words they have learned, and how to retain these words as part of their mental lexicon (Zahedi and Abdi, 2012: 2265), because the higher students' battery of vocabulary memory strategies, the higher size of vocabulary mastery, and the higher their proficiency level (Ansari, Zeynaldi and Mohrabi, 2000), and students who were taught vocabulary memory strategies, significant size of vocabulary mastery compared with the students who were not (Mahalle and Aidinlou, 2013). In other words, since teacherstudents relationship nowadays is suggested to be like partners, they may share tasks of language learning. Teacher provides communication activities and taught learning strategies in the classrooms processes as suggested by the current approaches and curriculum, and students learn vocabulary by themselves to be processed in the activities to enhance their English proficiency.

If so, the need of the current language teaching is not to teach vocabulary in the classroom but to equip students with strategies to learn vocabulary. Long ago, Palmer (1925, in Nation 2003) has suggested that the most fundamental guiding principle (for) those who are anxious to be proficient in foreign language conversation .... is 'memorize perfectly the largest number of common and useful word-groups'. It has been suggested that teaching vocabulary should not only consist of teaching specific words but also intend at equipping learners with strategies necessary to expand their vocabulary knowledge (Hulstjin, 1993, in 
Zahedi and Abdi, 2012). The next question must be to what are the most effective strategies to be used by students to memorize vocabulary? Many publications provides a number of memory strategies, however the writer believes that the most effective ways are those which are used by the successful English learners. Key components of investigation covered all strategies to memorize English vocabulary. The research investigated all strategy items which are listed in Schmitt and McChartys' (1997) and other strategies that the students' used out of the list. To obtain the data, relevant instruments was addressed to the gifted students of English Department students in IAIN Padangsidimpuan, at semester VII. To make clear, focus of the research was follows: 1) how is the use of strategies listed on Schmitt and McChartys' (1997) battery of vocabulary memory strategies by gifted students at English Deparment of IAIN Padangsidimpuan?; and 2) what are the other strategies used by gifted students at English Deparment of IAIN Padangsidimpuan, which are not listed in the package of vocabulary memory strategies?. Relevant with the objectives of the research, to clarify and to guide the investigation toward collecting the expected data, the objectives of the research were as follows: 1) to describe the use of strategies listed on Schmitt and McChartys' (1997) battery of vocabulary memory strategies by gifted students at English Deparment of IAIN Padangsidimpuan; 2) to identify the other strategies used by gifted students at English Deparment of IAIN Padangsidimpuan, which are not listed in the package of vocabulary memory strategies.

\section{RESEARCH METHOD}

Methodological scheme applied in conducting this research briefly is: Design of this was quantitative descriptive method that is to describe the finding by using numbers. It means that the exploration described the findings by using number. The respondents were the sixth semester students at English department of IAIN Padangsidimpuan, whose GPA was 3,5 and above, and whom are personally known to have shown excellent English performance in the classrooms. Students who fulfilled the criteria were 17 students, and they were all taken as source of data. Instruments for collecting data involved 1) questionnaire for gathering data about the use of strategies in Schmitt and McCharty's (1997), and 2) interview guidance for gathering the data about other strategies out of list and for maintaining the validity of the data. The data were collected by administering the questionnaire and doing the interview. Therefore, the data were analyzed by examining the quantitative features shown in them. 


\section{RESULTS AND DISCUSSION}

\section{Results}

This sub-section consists of two parts: 1) quantitative description about response distribution to the strategies listed in the package. The description begins from distribution in each strategy, as whole and then ended with order of sequence of the strategies based on frequency of its use; 2) description about other strategies that the respondents used for memorizing English words, which are not listed in the strategies package. The presentation consists of description of the process and identification of the respondents who used them. Therefore, results of data analysis are presented as follows:

1. The use of strategies listed in Schmitt and McChartys' (1997) battery of vocabulary memory strategies

From the data gathered in this study, it was seen variety distribution of response toward each item of the strategies. Necessarily, previous to the further stage of data analysis process based on objectives of the research, by abbreviating the responses: A: Almost Always, O: Often, S: Sometimes, R: Rarely, and N: Never, summary of the raw data is presented as follows:

Table 1. Summary of participants' response to Schmitt and McCharty's (1997) Package of Vocabulary Memory Strategies

\begin{tabular}{|c|c|c|c|c|c|c|c|c|c|c|c|c|c|c|c|c|c|}
\hline \multirow{2}{*}{$\begin{array}{r}\text { Item } \\
\text { Strg } \\
\end{array}$} & \multicolumn{17}{|c|}{ Participants' Responses } \\
\hline & 1 & 2 & 3 & 4 & 5 & 6 & 7 & 8 & 9 & 10 & 11 & 12 & 13 & 14 & 15 & 16 & 17 \\
\hline 1 & $\mathrm{O}$ & $\mathrm{R}$ & $\mathrm{S}$ & $\mathrm{O}$ & $\mathrm{S}$ & A & $\mathrm{R}$ & A & $\mathrm{R}$ & $\mathrm{S}$ & $\mathrm{R}$ & $\mathrm{O}$ & A & A & $\mathrm{R}$ & $\mathrm{S}$ & $\mathrm{O}$ \\
\hline 2 & $\mathrm{~N}$ & $\mathrm{O}$ & $\mathrm{O}$ & $\mathrm{O}$ & $\mathrm{S}$ & $\mathrm{O}$ & $\mathrm{R}$ & $\mathrm{S}$ & $\mathrm{R}$ & $\mathrm{S}$ & A & $\mathrm{O}$ & $\mathrm{R}$ & $\mathrm{O}$ & $\mathrm{S}$ & $\mathrm{O}$ & $\mathrm{O}$ \\
\hline 3 & $\mathrm{R}$ & $\mathrm{R}$ & $\mathrm{S}$ & $\mathrm{O}$ & $\mathrm{S}$ & $\mathrm{O}$ & $\mathrm{R}$ & A & $\mathrm{S}$ & A & $\mathrm{S}$ & $\mathrm{S}$ & $\mathrm{R}$ & $\mathrm{R}$ & A & $\mathrm{s}$ & $\mathrm{O}$ \\
\hline 4 & $\mathrm{~S}$ & $\mathrm{~N}$ & $\mathrm{~S}$ & $\mathrm{~S}$ & S & $\mathrm{S}$ & $\mathrm{O}$ & $\mathrm{O}$ & $\mathrm{R}$ & A & S & $\mathrm{O}$ & $\mathrm{R}$ & $\mathrm{S}$ & $\mathrm{R}$ & S & $\mathrm{S}$ \\
\hline 5 & $\mathrm{O}$ & $\mathrm{N}$ & $\mathrm{S}$ & $\mathrm{R}$ & $\mathrm{S}$ & $\mathrm{R}$ & $\mathrm{S}$ & $\mathrm{O}$ & $\mathrm{R}$ & A & $\mathrm{R}$ & $\mathrm{S}$ & $\mathrm{S}$ & $\mathrm{S}$ & $\mathrm{R}$ & $\mathrm{S}$ & $\mathrm{R}$ \\
\hline 6 & $\mathrm{O}$ & $\mathrm{R}$ & $\mathrm{S}$ & $\mathrm{N}$ & $\mathrm{R}$ & $\mathrm{R}$ & $\mathrm{N}$ & $\mathrm{S}$ & $\mathrm{R}$ & $\mathrm{S}$ & $\mathrm{S}$ & $\mathrm{S}$ & $\mathrm{N}$ & $\mathrm{N}$ & $\mathrm{N}$ & $\mathrm{R}$ & $\mathrm{N}$ \\
\hline 7 & $\mathrm{~N}$ & $\mathrm{R}$ & $\mathrm{S}$ & $\mathrm{N}$ & $\mathrm{R}$ & $\mathrm{R}$ & $\mathrm{R}$ & $\mathrm{S}$ & $\mathrm{N}$ & $\mathrm{R}$ & S & $\mathrm{R}$ & $\mathrm{R}$ & $\mathrm{R}$ & $\mathrm{N}$ & $\mathrm{N}$ & $\mathrm{R}$ \\
\hline 8 & $\mathrm{R}$ & $\mathrm{N}$ & $\mathrm{R}$ & $\mathrm{R}$ & $\mathrm{R}$ & $\mathrm{R}$ & $\mathrm{N}$ & $\mathrm{O}$ & $\mathrm{N}$ & $\mathrm{N}$ & $\mathrm{N}$ & S & $\mathrm{N}$ & $\mathrm{N}$ & $\mathrm{N}$ & $\mathrm{R}$ & $\mathrm{N}$ \\
\hline 9 & $\mathrm{R}$ & S & $S$ & $\mathrm{~N}$ & $\mathrm{~N}$ & $\mathrm{R}$ & S & A & $\mathrm{N}$ & $\mathrm{R}$ & $\mathrm{R}$ & $\mathrm{O}$ & $\mathrm{N}$ & $\mathrm{R}$ & $\mathrm{N}$ & $\mathrm{N}$ & $\mathrm{S}$ \\
\hline 10 & $\mathrm{O}$ & S & $\mathrm{O}$ & A & S & $\mathrm{O}$ & $S$ & A & $\mathrm{O}$ & $\mathrm{O}$ & $\mathrm{O}$ & $\mathrm{O}$ & $\mathrm{R}$ & S & $\mathrm{R}$ & $\mathrm{R}$ & $\mathrm{R}$ \\
\hline 11 & $\mathrm{O}$ & $\mathrm{R}$ & S & $\mathrm{O}$ & S & $S$ & S & A & $S$ & $\mathrm{O}$ & $\mathrm{R}$ & $\mathrm{O}$ & $\mathrm{R}$ & $\mathrm{R}$ & $\mathrm{R}$ & $\mathrm{R}$ & $\mathrm{R}$ \\
\hline 12 & $\mathrm{O}$ & S & $\mathrm{O}$ & $\mathrm{R}$ & $S$ & $S$ & $\mathrm{R}$ & S & $\mathrm{O}$ & $\mathrm{O}$ & $\mathrm{R}$ & S & $\mathrm{R}$ & $\mathrm{S}$ & $\mathrm{O}$ & S & $\mathrm{O}$ \\
\hline 13 & S & $\mathrm{R}$ & $\mathrm{R}$ & $\mathrm{O}$ & $\mathrm{O}$ & $\mathrm{R}$ & $\mathrm{O}$ & $\mathrm{S}$ & $\mathrm{N}$ & A & $\mathrm{S}$ & $\mathrm{R}$ & $\mathrm{R}$ & $\mathrm{N}$ & $\mathrm{N}$ & S & $\mathrm{R}$ \\
\hline 14 & $S$ & S & $\mathrm{O}$ & A & $\mathrm{O}$ & $\mathrm{O}$ & $\mathrm{R}$ & A & $\mathrm{O}$ & A & A & $\mathrm{O}$ & $S$ & $\mathrm{O}$ & A & $\mathrm{O}$ & $\mathrm{O}$ \\
\hline 15 & $S$ & S & $\mathrm{O}$ & A & $\mathrm{O}$ & $\mathrm{N}$ & $\mathrm{R}$ & $\mathrm{O}$ & S & A & $\mathrm{N}$ & S & S & $\mathrm{S}$ & A & S & $\mathrm{R}$ \\
\hline 16 & $S$ & S & $\mathrm{O}$ & A & $\mathrm{S}$ & $\mathrm{O}$ & $\mathrm{S}$ & A & $\mathrm{O}$ & A & A & $S$ & $\mathrm{R}$ & S & A & A & $\mathrm{S}$ \\
\hline 17 & $\mathrm{R}$ & $\mathrm{O}$ & $\mathrm{O}$ & $\mathrm{O}$ & S & $S$ & $\mathrm{~N}$ & $\mathrm{O}$ & $\mathrm{R}$ & S & A & $\mathrm{O}$ & $\mathrm{R}$ & A & $\mathrm{R}$ & $\mathrm{O}$ & S \\
\hline 18 & $\mathrm{R}$ & $\mathrm{R}$ & $\mathrm{S}$ & $\mathrm{N}$ & $\mathrm{S}$ & $\mathrm{R}$ & $\mathrm{R}$ & $\mathrm{S}$ & $\mathrm{N}$ & $\mathrm{N}$ & $\mathrm{N}$ & $\mathrm{R}$ & $\mathrm{N}$ & $\mathrm{R}$ & $\mathrm{N}$ & $\mathrm{N}$ & $\mathrm{N}$ \\
\hline 19 & S & $\mathrm{N}$ & $\mathrm{R}$ & $\mathrm{O}$ & S & S & $\mathrm{N}$ & $\mathrm{O}$ & $\mathrm{N}$ & S & A & S & $\mathrm{R}$ & $\mathrm{N}$ & $\mathrm{N}$ & $\mathrm{N}$ & $\mathrm{R}$ \\
\hline 20 & S & S & $\mathrm{O}$ & A & S & $S$ & $\mathrm{O}$ & $\mathrm{O}$ & $S$ & A & $\mathrm{O}$ & $\mathrm{O}$ & $\mathrm{N}$ & $\mathrm{R}$ & $\mathrm{O}$ & $\mathrm{O}$ & $\mathrm{O}$ \\
\hline 21 & $\mathrm{O}$ & S & S & $\mathrm{O}$ & $\mathrm{O}$ & $\mathrm{R}$ & $\mathrm{O}$ & S & $\mathrm{N}$ & A & $\mathrm{O}$ & $\mathrm{R}$ & $\mathrm{N}$ & $\mathrm{N}$ & $\mathrm{R}$ & $\mathrm{R}$ & $\mathrm{R}$ \\
\hline 22 & $\mathrm{O}$ & S & $\mathrm{O}$ & S & S & $\mathrm{R}$ & $\mathrm{R}$ & $\mathrm{O}$ & S & A & A & S & $\mathrm{R}$ & $\mathrm{R}$ & $\mathrm{R}$ & $\mathrm{N}$ & $\mathrm{R}$ \\
\hline 23 & $\mathrm{O}$ & $\mathrm{O}$ & $\mathrm{O}$ & $S$ & $S$ & $\mathrm{O}$ & $\mathrm{R}$ & A & $\mathrm{N}$ & $S$ & A & $S$ & $\mathrm{R}$ & $S$ & $S$ & S & S \\
\hline 24 & $\mathrm{R}$ & $\mathrm{R}$ & $\mathrm{S}$ & $\mathrm{O}$ & S & $\mathrm{N}$ & $\mathrm{O}$ & $\mathrm{O}$ & $\mathrm{R}$ & $\mathrm{R}$ & $S$ & S & $\mathrm{R}$ & $\mathrm{R}$ & $\mathrm{O}$ & S & $\mathrm{R}$ \\
\hline
\end{tabular}




\begin{tabular}{cccccccccccccccccc}
\hline Item & \multicolumn{11}{c}{ Participants' Responses } \\
\cline { 2 - 15 } Strg & 1 & 2 & 3 & 4 & 5 & 6 & 7 & 8 & 9 & 10 & 11 & 12 & 13 & 14 & 15 & 16 & 17 \\
\hline 25 & $\mathrm{~N}$ & $\mathrm{R}$ & $\mathrm{S}$ & $\mathrm{S}$ & $\mathrm{S}$ & $\mathrm{N}$ & $\mathrm{S}$ & $\mathrm{O}$ & $\mathrm{N}$ & $\mathrm{A}$ & $\mathrm{S}$ & $\mathrm{R}$ & $\mathrm{N}$ & $\mathrm{S}$ & $\mathrm{O}$ & $\mathrm{R}$ & $\mathrm{S}$ \\
26 & $\mathrm{~N}$ & $\mathrm{~S}$ & $\mathrm{~S}$ & $\mathrm{R}$ & $\mathrm{R}$ & $\mathrm{S}$ & $\mathrm{S}$ & $\mathrm{O}$ & $\mathrm{N}$ & $\mathrm{N}$ & $\mathrm{N}$ & $\mathrm{O}$ & $\mathrm{S}$ & $\mathrm{R}$ & $\mathrm{S}$ & $\mathrm{R}$ & $\mathrm{S}$ \\
27 & $\mathrm{R}$ & $\mathrm{N}$ & $\mathrm{R}$ & $\mathrm{N}$ & $\mathrm{R}$ & $\mathrm{N}$ & $\mathrm{S}$ & $\mathrm{S}$ & $\mathrm{N}$ & $\mathrm{S}$ & $\mathrm{S}$ & $\mathrm{R}$ & $\mathrm{N}$ & $\mathrm{N}$ & $\mathrm{N}$ & $\mathrm{N}$ & $\mathrm{N}$ \\
\hline
\end{tabular}

Therefore, distribution of participants' responses to each strategy is shown in the following table.

Table 2. Participants' responses distribution to each strategy in Scmitt and McCharty's (1997) Package of Vocabulary Strategies

\begin{tabular}{|c|c|c|c|c|c|c|}
\hline \multirow[t]{2}{*}{ Strategies } & \multicolumn{6}{|c|}{ Response Distribution (Number and Percent) } \\
\hline & Almost Always & Often & Sometimes & Rarely & Never & Total \\
\hline Strategy 1 & 4 & 4 & 4 & 5 & 0 & 17 \\
\hline Strategy 2 & 1 & 8 & 4 & 3 & 1 & 17 \\
\hline Strategy 3 & 3 & 3 & 6 & 5 & 0 & 17 \\
\hline Strategy 4 & 1 & 3 & 9 & 3 & 1 & 17 \\
\hline Strategy 5 & 1 & 2 & 7 & 6 & 1 & 17 \\
\hline Strategy 6 & 0 & 1 & 5 & 5 & 6 & 17 \\
\hline Strategy 7 & 0 & 0 & 3 & 9 & 5 & 17 \\
\hline Strategy 8 & 0 & 1 & 1 & 6 & 9 & 17 \\
\hline Strategy 9 & 1 & 1 & 4 & 5 & 6 & 17 \\
\hline Strategy 10 & 2 & 7 & 4 & 4 & 0 & 17 \\
\hline Strategy 11 & 1 & 4 & 5 & 7 & 0 & 17 \\
\hline Strategy 12 & 0 & 6 & 7 & 4 & 0 & 17 \\
\hline Strategy 13 & 1 & 3 & 4 & 5 & 4 & 17 \\
\hline Strategy 14 & 5 & 8 & 3 & 1 & 0 & 17 \\
\hline Strategy 15 & 2 & 8 & 3 & 2 & 2 & 17 \\
\hline Strategy 16 & 6 & 3 & 7 & 1 & 0 & 17 \\
\hline Strategy 17 & 2 & 6 & 4 & 4 & 1 & 17 \\
\hline Strategy 18 & 0 & 0 & 3 & 6 & 8 & 17 \\
\hline Strategy 19 & 1 & 2 & 5 & 3 & 6 & 17 \\
\hline Strategy 20 & 2 & 8 & 5 & 1 & 1 & 17 \\
\hline Strategy 21 & 1 & 5 & 3 & 5 & 3 & 17 \\
\hline Strategy 22 & 2 & 3 & 5 & 6 & 1 & 17 \\
\hline Strategy 23 & 2 & 4 & 8 & 2 & 1 & 17 \\
\hline Strategy 24 & 0 & 4 & 5 & 7 & 1 & 17 \\
\hline Strategy 25 & 1 & 2 & 7 & 3 & 4 & 17 \\
\hline Strategy 26 & 0 & 2 & 7 & 4 & 4 & 17 \\
\hline Strategy 27 & 0 & 0 & 4 & 4 & 9 & 17 \\
\hline Number & 39 & 98 & 132 & 116 & 74 & 459 \\
\hline Percentage & $8,5 \%$ & $21,4 \%$ & $28,8 \%$ & $25,3 \%$ & $16,1 \%$ & $100 \%$ \\
\hline
\end{tabular}

The table above shows that from the amount 459 responses (27 strategies $\mathrm{x} 17$ respondents), the distribution is: Almost Always: 39 responses (8,5\%), Often: 98 (21,4\%), Sometimes: 132 (28,8\%), Rarely: 116 (25,3\%), and Never: 74 (16,1\%). The distribution shown does not represent any value of practice to whether the score is high or low, or good or bad, because conceptually, the use of a certain strategy item influences the use of the others.

The data analysis also shows that all strategies were used by the students, but the frequency was widely different. To acquire description of frequency sequence used by the 
participants, used scoring system developed by Oxford (1990), that is: Almost Always: 5, Often: 4, Sometimes: 3, Rarely: 2 and Never: 1. The frequency score distribution sequenced from the highest to the lowest is as follows:

\begin{tabular}{|c|c|c|c|c|c|c|c|c|c|c|c|c|c|c|c|c|c|c|}
\hline \multicolumn{18}{|c|}{ Participants' Responses Scores } & \multirow{2}{*}{$\begin{array}{c}\mathrm{A} \\
\mathrm{mt}\end{array}$} \\
\hline Strategy & 1 & 2 & 3 & 4 & 5 & 6 & 7 & 8 & 9 & 10 & 11 & 12 & 13 & 14 & 15 & 16 & 17 & \\
\hline 14 & 3 & 3 & 4 & 5 & 4 & 4 & 2 & 5 & 4 & 5 & 5 & 4 & 3 & 4 & 5 & 4 & 4 & 68 \\
\hline 16 & 3 & 3 & 4 & 5 & 3 & 4 & 3 & 5 & 4 & 5 & 5 & 3 & 2 & 3 & 5 & 5 & 3 & 65 \\
\hline 20 & 3 & 3 & 4 & 5 & 3 & 3 & 4 & 4 & 3 & 5 & 4 & 4 & 1 & 2 & 4 & 4 & 4 & 60 \\
\hline 10 & 4 & 3 & 4 & 5 & 3 & 4 & 3 & 5 & 4 & 4 & 4 & 4 & 2 & 3 & 2 & 2 & 2 & 58 \\
\hline 1 & 4 & 2 & 3 & 4 & 3 & 5 & 2 & 5 & 2 & 3 & 2 & 4 & 5 & 5 & 2 & 3 & 4 & 58 \\
\hline 2 & 1 & 4 & 4 & 4 & 3 & 4 & 2 & 3 & 2 & 3 & 5 & 4 & 2 & 4 & 3 & 4 & 4 & 56 \\
\hline 23 & 4 & 4 & 4 & 3 & 3 & 4 & 2 & 5 & 1 & 3 & 5 & 3 & 2 & 3 & 3 & 3 & 3 & 55 \\
\hline 17 & 2 & 4 & 4 & 4 & 3 & 3 & 1 & 4 & 2 & 3 & 5 & 4 & 2 & 5 & 2 & 4 & 3 & 55 \\
\hline 3 & 2 & 2 & 3 & 4 & 3 & 4 & 2 & 5 & 3 & 5 & 3 & 3 & 2 & 2 & 5 & 3 & 4 & 55 \\
\hline 15 & 3 & 3 & 4 & 5 & 4 & 1 & 2 & 4 & 3 & 5 & 1 & 3 & 3 & 3 & 5 & 3 & 2 & 54 \\
\hline 12 & 4 & 3 & 4 & 2 & 3 & 3 & 2 & 3 & 4 & 4 & 2 & 3 & 2 & 3 & 4 & 3 & 4 & 53 \\
\hline 4 & 3 & 1 & 3 & 3 & 3 & 3 & 4 & 4 & 2 & 5 & 3 & 4 & 2 & 3 & 2 & 3 & 3 & 51 \\
\hline 22 & 4 & 3 & 4 & 3 & 3 & 2 & 2 & 4 & 3 & 5 & 5 & 3 & 2 & 2 & 2 & 1 & 2 & 50 \\
\hline 11 & 4 & 2 & 3 & 4 & 3 & 3 & 3 & 5 & 3 & 4 & 2 & 4 & 2 & 2 & 2 & 2 & 2 & 50 \\
\hline 21 & 4 & 3 & 3 & 4 & 4 & 2 & 4 & 3 & 1 & 5 & 4 & 2 & 1 & 1 & 2 & 2 & 2 & 47 \\
\hline 5 & 4 & 1 & 3 & 2 & 3 & 2 & 3 & 4 & 2 & 5 & 2 & 3 & 3 & 3 & 2 & 3 & 2 & 47 \\
\hline 24 & 2 & 2 & 3 & 4 & 3 & 1 & 4 & 4 & 2 & 2 & 3 & 3 & 2 & 2 & 4 & 3 & 2 & 46 \\
\hline 25 & 1 & 2 & 3 & 3 & 3 & 1 & 3 & 4 & 1 & 5 & 3 & 2 & 1 & 3 & 4 & 2 & 3 & 44 \\
\hline 13 & 3 & 2 & 2 & 4 & 4 & 2 & 4 & 3 & 1 & 5 & 3 & 2 & 2 & 1 & 1 & 3 & 2 & 44 \\
\hline 26 & 1 & 3 & 3 & 2 & 2 & 3 & 3 & 4 & 1 & 1 & 1 & 4 & 3 & 2 & 3 & 2 & 3 & 41 \\
\hline 19 & 3 & 1 & 2 & 4 & 3 & 3 & 1 & 4 & 1 & 3 & 5 & 3 & 2 & 1 & 1 & 1 & 2 & 40 \\
\hline 9 & 2 & 3 & 3 & 1 & 1 & 2 & 3 & 5 & 1 & 2 & 2 & 4 & 1 & 2 & 1 & 1 & 3 & 37 \\
\hline 6 & 4 & 2 & 3 & 1 & 2 & 2 & 1 & 3 & 2 & 3 & 3 & 3 & 1 & 1 & 1 & 2 & 1 & 35 \\
\hline 7 & 1 & 2 & 3 & 1 & 2 & 2 & 2 & 3 & 1 & 2 & 3 & 2 & 2 & 2 & 1 & 1 & 2 & 32 \\
\hline 27 & 2 & 1 & 2 & 1 & 2 & 1 & 3 & 3 & 1 & 3 & 3 & 2 & 1 & 1 & 1 & 1 & 1 & 29 \\
\hline 18 & 2 & 2 & 3 & 1 & 3 & 2 & 2 & 3 & 1 & 1 & 1 & 2 & 1 & 2 & 1 & 1 & 1 & 29 \\
\hline 8 & 2 & 1 & 2 & 2 & 2 & 2 & 1 & 4 & 1 & 1 & 1 & 3 & 1 & 1 & 1 & 2 & 1 & 28 \\
\hline
\end{tabular}

In words, the vocabulary memory strategies' (Schmitt and McCharty, 1997) sequence of use by the participants is as follows
a) Strategy 14. Study the spelling of a word
b) Strategy 16. Say new word aloud when studying
c) Strategy 20. Use keyword Method
d) Strategy 10. Group words together to study them
e) Strategy 1. Study word with a pictorial representation of its meaning
f) Strategy 2. Imagine word's meaning
g) Strategy 23. Paraphrase the word's meaning
h) Strategy 17. Imagine word form
i) Strategy 3. Connect word to a personal experience
j) Strategy 15. Study the sound of a word
k) Strategy 12. Use new word in sentence 
1) Strategy 4. Associate the word with its coordinates

m) Strategy 22. Part of speech (rebering)

n) Strategy 11. Group words together spatially on a page

o) Strategy 21. Affixes and roots (rebering)

p) Strategy 5. Connect the word to its synonyms and antonyms

q) Strategy 24. Use cognates in study

r) Strategy 25. Learn the words of an idiom together

s) Strategy 13. Group words together of a word

t) Strategy 26. Use physical action when learning a word

u) Strategy 19. Configuration

v) Strategy 9. Loci Method

w) Strategy 6. Use semantic maps

x) Strategy 7. Use "scales" for gradable adjectives

y) Strategy 27. Use semantic feature grids

z) Strategy 18. Underline initial letter of the word

aa) Strategy 8. Peg Method

2. Vocabulary memory strategies that students use out of the package

Resulted from checked and rechecked interviews (there times of interviews), there are 8 other strategies used by the participants to memorize English vocabulary, which are not listed in Schmitt and McChartys (1997) package. The strategies are presented based on frequency of use as follows:

a) Picking words from English movies and song, consulting dictionary for the meaning. This strategy was conducted by six respondents.

b) Making world wall. This strategy was used by three respondents.

c) Writing boldly the words in a piece of paper and then put them in special box. This strategy was practiced by one respondent.

d) Making song lyrics by using the new words and then sing the lyrics. This strategy was used by one respondent.

e) Making poets by using new words and then read the poets aloud. This strategy was practiced by one respondent.

f) Intentionally using new words in English conversation. This strategy was conducted by one student.

g) Memorizing English songs. This strategy was used by one student.

h) Writing the new words in hand phone notes. This strategy was practiced by one student. 


\section{Disccusion}

1. The use of strategies listed in Schmitt and McChartys' (1997) battery of vocabulary memory strategies

Findings of this research at this point, reveal the high randomness of vocabulary use among the students, in which all strategies are used, but the frequency is different. It clearly suggests that doing learning is more important than how to learn, the findings distinctively show that different strategy can work successfully to different learners. It reconfirms Noor and Amir's (2000) findings about variedness of vocabulary learning strategies used by Malay students, and supports Brown's (1994) suggestion to teach as many as possible vocabulary learning strategies to the students.

That different gifted students used different strategies to memorize English vocabulary found in this study, indicates that they should have different psychological and environmental features relating to their choice of vocabulary learning strategies. Again it supports Gardner's (1993) and Brown's (1994) suggestion to investigate students' psychological backgrounds preceding the teaching and learning activities. This effort will enable teacher to introduce appropriate teaching strategies and to teach appropriate learning strategies to students.

Sequence of vocabulary learning strategies listed in Schmitt and McChartys' (1997) found in this research, strengthens and gives meaningful addition to Noor and Amir (2000) findings about vocabulary strategies used by Malay students: memorization > dictionary strategies $>$ linguistic clues. The sequence would be useful contribution to teachers about choice of learning strategies to be taught in the school.

2. Other strategies used by the students, which are not listed in the package of Schmitt and McChartys' (1997) battery of vocabulary memory strategies

Through this research, there are 8 other strategies found which are not listed in Schmitt and McCharty's (1997) package. Relating to it, the 8 new strategies are useful addition to the discussion and discourse of vocabulary memory strategies in the future, which can be a new starting point for the next researcher for conducting further investigation and for the teachers of English for teaching more items of vocabulary memory strategies to students in their classrooms. 


\section{CONCLUSION}

From findings and discussion of this research presented above, and based the purposes of this study, generated the following conclusions:

1. All strategies listed in Schmitt and McChartys' (1997) package was used by the participants, but the frequency of use revealed high randomness. The total responses distribution is: from 459 responses distributed to almost always: 39 responses (8,5\%), often: 98 responses (21,4\%), sometimes: 132 responses (28\%), rarely: 116 responses $(25,3 \%)$ and never: 74 responses $(16,1 \%)$. Strategies items sequence of use from the highest to the lowest is: Strategy $14>16>20>10=1>2>23=17=3>15>12>4>22=11>21=5>$ $24>25=13>26>9>6>7>27=18>8$.

2. Strategies that students used out of Schmitt and McChartys' (1997) package, listed from the highest use to the lowest are: 1) Picking words from English movies and song, consulting dictionary for the meaning, 2) Making word wall, 3) Writing boldly the words in a piece of paper and then put them in a special box, 4) Making song lyrics by using the new words and then sang the lyrics, 5) Making poets by using new words and then read the poets aloud, 6) Intentionally using new words in English conversation, 7) Memorizing English songs, and 8)Writing the new words in hand phone notes.

\section{REFERENCES}

Ansarin, A.A, M. Zohrabi and S. Zeynaldi. (2012). Language Learning Strategies and Vocabulary Size of Iranian EFL Learners.Theory and Practice in Language Studies, 2 (9): 1841-1848.

Benjamin, Aaron. (2007). Memory is More than Just Remembering: Strategic Control of Encoding, Accessing Memory, and Making Decisions. in Benjamin and Ross (Ed). Skills and Strategy in Memory Use. Oxford: Elsevier

Brown, Richards H. (1994). Teaching by Principles: An Interactive Approach to Language

Pedagogy. New Jersey: Prentice Hall Regents

Collins Cobuild Dictionary on CD Room. (2006). Harper Collins Publisher.

Gardner, H. (1993). Multiple Intelligences: The Theory and Practice. New York: Basic Books.

Hunt, Alan \& David Berglar. (2004). Current Research in Teaching Vocabulary. In Richards and Renandya (Ed). Methodology in Language Teaching. Cambridge: Cambridge University Press 
Jobrack, Beverlee. (2011). Developing Academic Vocabulary. STEM White Paper.

Mahalle, M.T.V and N.A Aidinlou. (2013). An Investigation of the Effects of G5 Mnemonic Technique in Learning Vocabulary among Iranian EFL Learners. International Journal of Linguistics, 5 (2).

Noor, Noorizah. Mohd. and Zaini Amir. (2000). Exploring the Vocabulary Learning Strategies of EFL Learners. Kuala Lumpur: Universiti KebangsaanMalaysia

Oxford, R. (1990). Language Learning Strategies: What Every Teacher Should Know. New York: Newbury House.

Schmitt, N., \& McCarthy, M. (Eds). (1997). Vocabulary, Description, Acquisition, and Pedagogy: Vocabulary Learning Strategies. Cambridge: Cambridge University Press.

Seal, Bernard D. (1991). Vocabulary Learning and Teaching. In Celce-Murcia, M. (Ed). Teaching Engish as Second or Foreign Language. New York: Newbury House

Zahedi, Yagoub and Mortaza Abdi. (2012). The Impact of Imagery Strategy on EFL learners' Vocabulary Learning. Procedia - Social and Behavioral Sciences, 69. 